\section{KDO OBISKUJE SVETOVALNA SREDIŠČA ZA ODRASLE}

\section{Svetovalna središča - dejavnik pospeševanja izobraževanja}

Ana Granda

Jakše,

Razvojno-

izobraževalni

center Novo

mesto

\title{
POVZETEK
}

$V$ prispevku so predstavljeni rezultati enoletnega spremljanja informiranja in svetovanja odraslim za izobraževanje v Svetovalnem središču Novo mesto. Predstaviti želimo demografske podatke oseb, ki so se v letu 2002 odločile za obisk svetovalnega središča, in vsebine njihovih obiskov.

Za obisk svetovalnih središč se odločajo predvsem mlajši od 35 let, ki potrebujejo zlasti pomoč pri odločanju za formalne oblike izobraževanja. Proces vseživljenjskega učenja predpostavlja vključevanje širših množic in ne izključuje določenih ciljnih skupin, enakovrednejšse mesto pa naj bi imele tako formalne kot tudi neformalne poti učenja in izobraževanja.

Ključne besede: svetovanje, informiranje, vseživljenjsko izobraževanje, izobraževanje odraslih, motiviranje

\section{UVOD}

Okolje, $v$ katerem živimo danes, se spreminja z veliko naglico. Zaradi hitrega razvoja komunikacijskih sredstev se zdi, kot da nas naenkrat obdaja velika količina informacij, ki smo jim vedno težje kos. Kljub temu, da je civilizacija prišla do te mere razvitosti, ko je človeku na voljo $\mathrm{z}$ malo truda skoraj vse, pa se razlike med tistimi, ki imajo, in tistimi, ki nimajo, iz dneva $v$ dan povečujejo. Velikokrat je most med imeti in ne imeti prav izobrazba, saj je njeno pomanjkanje - poleg telesnih, socialnih ali kakršnihkoli drugačnih primanjkljajev - pogosto tista ovira, ki določen sloj ljudi vedno pušča osamljene, brez pomoči, nekje na robu.

$V$ času popularizacije ideje permanentnega jzobraževanja, liberalizacije izobraževanja in velike količine informacij, ki so na voljo $\mathrm{v}$ zelo razliěnih oblikah, je potrebno poudariti, da še vedno obstaja veliko tistih, ki se ravno zaradi neizobraženosti, zastarelosti znanja in specifiěnosti ter nezahtevnosti delovnega mesta (če ga seveda sploh imajo), ne znajo dokopati do informacij, poiskati pomoči in se samostojno, zrelo in pravilno odločati. Odrasli se od otrok razlikujejo tudi po tem, da so velikokrat izolirani od informacij in "mreže" kontaktov, povezanih z izobraževanjem. (Woolfe, 1987, str. 139)

Prav zaradi tega se ljudje, ki imajo težave, vedno pogosteje obračajo $\mathrm{k}$ tistim vrstam pomoči, ki nudijo oseben stik s človekom. Osebni stik ponuja ljudem, ki so $\mathrm{v}$ stiski, predvsem dvoje - posameznik s pomočjo nekoga drugega poskușa ovrednotiti informacije in jih postaviti v svoj miselni koncept in življenjske okoliščine, poleg tega pa ima pogovor vedno tudi terapevtsko oziroma 
mentalno higiensko funkcijo. (Kristančič, 1995)

Poudariti je treba, dá se odrasli praviloma odločajo za izobraževanjes točno določenim namenom, največkrat pa zato, da bi izboljšali ali si pridobili znanje, kar bi prineslo pozitivne učinke na več ravneh - večje zadovoljstvo, znanje za opravljanje dela, ohranitev ali pridobitev delovnega mesta, povečanje zaslužka ... (Tujinman, 1996, v Vilič Klenovšek, 1998a, str. 30)

"V izobraževanju otrok in mladine so se svetovalne službe in dejavnosti uveljavile že pred časom: poznamo svetovanje staršem in otrokom ob učnih in vzgojnih težavah, poklicno usmerjanje, šolske svetovalne delavce, psihologe ipd. V izobraževanju odraslih pa posebnih svetovaInih služb ali dejavnosti svetovanja v izobraževanju odraslih ne poznamo; tudi tam, kjer izobraževalna dejavnost poteka na šolah, $v$ večini primerov tam zaposleno svetovalno osebje ne opravlja uslug tudi za odrasle." (Vilič Klenovšek, 1998b, str. 2)

V Sloveniji je jeseni leta 2001 zaživelo 5 svetovalnih središč (Svetovalno središče Koper, Svetovalno središče Novo mesto, Svetovalno središče Žalec, Svetovalno središče Maribor, Svetovalno središče Murska Sobota), leta 2002 pa še 3 (Svetovalno središče Postojna, Svetovalno središče Jesenice, Svetovalno središče Zasavje), ki so namenjena informiranju in svetovanju odraslim za izobraževanje. Dejavnost svetovalnih središč finančno podpira Ministrstyo za šolstvo, znanost in šport. Uvajali smo jih postopoma eno leto pod strokovnim vodstvom Andragoškega centra Slovenije in so plod raziskave okolja ter dogovorov in sporazumov strateških in strokovnih partnerjev, ki središča podpirajo in skrbijo za promocijo v okolju.

Namen našega prispevka je ugotoviti in pokazati, kdo so ljudje, ki se odločajo za obisk Svetovalnega središča Novo mesto, in zaradi kakšnil problemov se obrnejo na svetovalno središče. Študija primera se nanaša na koledarsko leto 2002, podatke pa smo pridobili s pomočjo obrazca za spremljanje svetovalnih storitev ISIO 2.

\section{INFORMIRANIE IN SVETOVANIE ODRASLIM ZA IZOBRAŽEVANJE V LUČI IDEJE PERMANENTNEGA IZOBRAŽEVANIA}

Izobraževanje je prav gotovo ena izmed tistih dobrin, ki lahko vpliva na kakovost življenja posameznika, vedno pogosteje pa postaja nuja in "pogoj za preživetje". Znanja, ki jih dobimo v sistemu začetnega izobraževanja, zaradi naglega razvoja hitro zastarijo. Učenje se iz dobe otroštva in mladostništva širi na vse življenje. (Jelenc, 1998)

Cilj permanentnega izobraževanja je predvsem ljudem omogočiti fleksibilnost med različnimi učnimi priložnostmi oziroma situacijami, zaposlitvijo, regijami in državami, čim bolj izkoristiti znanje in sposobnosti. Tako vseživljenjsko učenje ni omejeno le na ekonomski vidik ali samo na izobraževanje odraslih. Sega na vsá področja, od predšolskega pa vse do tretjega življenjskega obdobja, in zajema celoten spekter formalnega in neformalnega izobraževanja. Glavni cilji takega učenja so poleg že naštetih tudi aktivno državljanstvo, osebna izpolnitev in socialna vključenost. Osnovni principi, s katerimi se udejanja vseživljenjsko učenje, so usmerjenost $\mathrm{k}$ tistemu, ki se uči, in poudarjanje enakih možnosti za učenje.

P. Lengrand v svojem delu pravi, da je ideja o vseživljenjskem učenju krožna: vseživljenjsko učenje je vredno svojega imena le, če so ljudje $v$ otroštvu deležni poštene in razumne izobrazbe, ki temelji na življenjskih potrebah in je pojasnjena, prepojena $\mathrm{z}$ ugotovitvami sociologije, psihologije, telesno in duševno higieno. Kljub temu pa take vrste izobrazbe 
ni mogoče doseči, če izobraževanje v odrasli dobi ni trdno zasidrano $v$ mišljenju ljudi, če izobraževanje odraslih ni način življenja in če nima trdne zakonske osnove. (Lengrand, 1975, v Lifelong and Continuing Education, 2001)

Vseživljenjsko učenje je proces, ki poteka "od zibke do groba". Ima horizontalno in vertikalno dimenzijo - vsestransko zaobjema učenje, ki se poraja v vsakem vidiku življenja, pri delu, doma, v prostem času, pri igri. Medtem ko formalno učenje vključuje učenje v različnih organizacijah, ima pojem učenje tudi dimenzijo. Ta obsega številne učne pristope in učne situacije, oddaljuje se od primata formalnega izobraževanja in še bolj od oblik institucionalnega učenja. (Field, Leicester, 2000)

Vseživljenjsko učenje v prihodnosti pogojuje razširjanje informaeij o različnih izobraževalnih aktivnostih in učnih možnostih po čim več različnih poteh. Različni izobraževalni programi bodo na voljo $v$ izobraževalnih centrih, doma, na delovnem mestu - kjerkoli bo posameznik želel. Uporabljati jih bo mogoče v različnih oblikah - kot samostojno učenje in učenje na daljavo ali $v$ tradicionalnih oblikah. Izobraževalne institucije bodo odprte za vse, ki se želijo vključevati, ne glede na to, ali bodo na koncu opravljali različna preverjanja znanja. Če pa se bodo znanja preverjala, bodo morale biti upoštevane tudi vse življenjske in delovne izkušnje. (Longworth, Davies, 1996)

Ena izmed primarnih stvari, ki idejo permanentnega izobraževanja spreminjajo iz teorije v prakso, je vzpostavitev učinkovitega informiranja in svetovanja za izobraževanje. Posamezniki tako dobịjo možnost za lažje zbiranje podatkov in svetovanje za izobraževanje, tako formalno kot neformalno. Vseživljenjsko izobraževanje predpostavlja fleksibilne in zelo različne poti učenja, ki so z učinkovitimi svetovalnimi službami lažje uresničljive. (Lifelong Learning and Lifewide Learning, 2000)

\section{INFORMIRANJE IN SVETOVANJE V IZOBRAŽEVANJU ODRASLIH - DEJAVNIK POSPEŠEVANJA IZOBRAŽEVANJA IN UČENJA ODRASLIH}

Odrasli se za izobraževanje odločajo iz zelo različnih motivov, velikokrat pa je odločitev bolj kot z osebno rastjo in prijetnim povezana z življenjsko nujnimi odločitvami.

V svetu, ki se spreminja hitro in nepričakovano, je zagotova ena stvar. Kakovost naših življenj je odvisna od naše zmožnosti pozitivnega odzivanja na nove izzive in priložnosti. V prihodnosti bomo morali postati bolj usposobljeni, izobraženi in prilagodljivi. Da bi lahko uresničili vse to, bomo morali nenehno iskati nove priložnosti za razvoj naših možnosti in talentov. (UDACE, 1986)

Odrasli se za učenje ali izobraževanje odločajo ponavadi prostovoljno, največkrat pa zaradi:

- razvijanja spretnosti, povezanih z njihovo zaposlitvijo,

- želje ali potrebe po pridobitvi nove kvalifikacije,

- želje po osebnostnem razvoju,

- Želje po kakovostnem preživljanju prostega časa. (Sutcliffe, 1990)

Odrasli se velikokrat ne srečujejo z odločanjem o tem, kaj in kako se učiti. Pogosto se dogaja tudi, da so možnosti za izobraževanje in učenje, ki so odraslim na voljo, zelo omejene. Pri razvijanju "k učencu" usmerjenega pristopa $v$ izobraževanju odraslih je pomembno, da se vprašamo tudi, kako lahko odraslim omogočimo dostop do informacij o tem, kakšne izobraževalne možnosti so jim na voljo, kako lahko odraslemu pomagamo 
pri odločanju za učenje in izobraževanje ter kakšne vrste pomoči je potrebno razvijati, da bi se odrasli bolj uspešno učili. (Prav tam.)

Namen svetovalnega dela $v$ izobraževanju odraslih je izenačiti razlike med izobraževalnimi potrebami in željami odraslih ter izobraževalnimi možnostmi, ki so jim na voljo. Najprej je tu pomoč posameznikom pri odkrivanju potreb in interesov, ob tem pa tudi pomoč pri izbiri med številnimi možnostmi skupaj z vsemi zahtevami in ovirami. (UDACE, 1986, str. 7)

Organizacije, ki se ukvarjajo s svetovalnim delom v izobraževanju, zbirajo informacije in potrebe, ki jih lahko posredujejo tisti, ki skrbijo za izobraževalno ponudbo. Svetovalno delo v izobraževanju odraslih ima dvojen pomen:

- pomoč odraslemu posamezniku v izobraževanju,

- oblikovanje ponudbe izobraževanja za odrasle. (UDACE, 1986, str. 7)

\section{KDO SO ODRASLI, KI SE ODLOČAJO ZA OBISK SVETOVALNEGA SREDIŠČA NOVO MESTO}

Svetovalno središce Novo mesto je služba, ki odraslim ponuja informiranje in svetovanje pred, med in po vključitvi v izobraževanje. Deluje na območju Mestne občine Novo mesto ter občin Žužemberk, Mirna Peč, Dolenjske Toplice, Škocjan in Šentjernej. Glede na to, da je Svetovalno središče Novo mesto edino na območju Dolenjske, Bele krajine in Posavja, stranke pogosto prihajajo tudi z omenjenih območij.

\section{ŠTEVILO STORITEV V LETU 2002}

V letu 2002 je bilo v Svetovalnem središču Novo mesto opravljenih 1249 svetovaInih storitev. S pojmom svetovalna storitev je mišljen vsak obisk, telefonski klic ali vsaka posamična storitev po pošti ali prek elektronske pošte; tudi če je ista oseba poiskala pomoč večkrat zaporedoma oziroma je bilo. za rešitev problema potrebnih več obiskov, telefonskih klicev ...

Iz tabele 1 je mogoče razbrati, da je storitev največ $\mathrm{v}$ septembru in oktobru, sledita meseca januar in februar ter avgust, marec in april. Obisk je najmanjši decembra in junija.

Iz podatkov je že mogoče sklepati, da je število obiskov v središču največje v mesecih pred vpisi v srednješolske programe in ob razpisih Ministrstva za znanost, šolstvo in šport. Ali je porast storitev res posledica vpisov in razpisov, bomo lahko sklepali tudi iz podatkov o vsebini povpraševanj obiskovalcev središča in podatkov o tistih, ki najpogosteje obiskuje Svetovalno središče Novo mesto. Seveda moramo poudariti, da se tako jeseni kot tudi $y$ začetku leta zvrstijo tudi vpisi $\mathrm{v}$ različne oblike neformalnih oblik izobraževanja, med katerimi prevladujejo jezikovni tečaji in različna računalniška izobraževanja, študijski krožki, dejavnosti Univerze za tretje življenjsko obdobje in še

Tabela 1: Śtevilo storitev svetovalnega središča po mesecih

\begin{tabular}{c|c|c|c|c|c|c|c|c|c|c|c|c|c} 
MESEC & JAN. & FEB. & MAR. & APR. & MAJ & JUN. & JUL. & AVG. & SEP. & OKT. & NOV. & DEC. & SKUPAJ \\
\hline $\begin{array}{c}\text { ŠTEVILO } \\
\text { STORITEV }\end{array}$ & 150 & 144 & 99 & 98 & 73 & 65 & 21 & 111 & 198 & 166 & 79 & 45 & 1249
\end{tabular}




\section{Slika 1: Število storitev svetovalnega središča po mesecih}

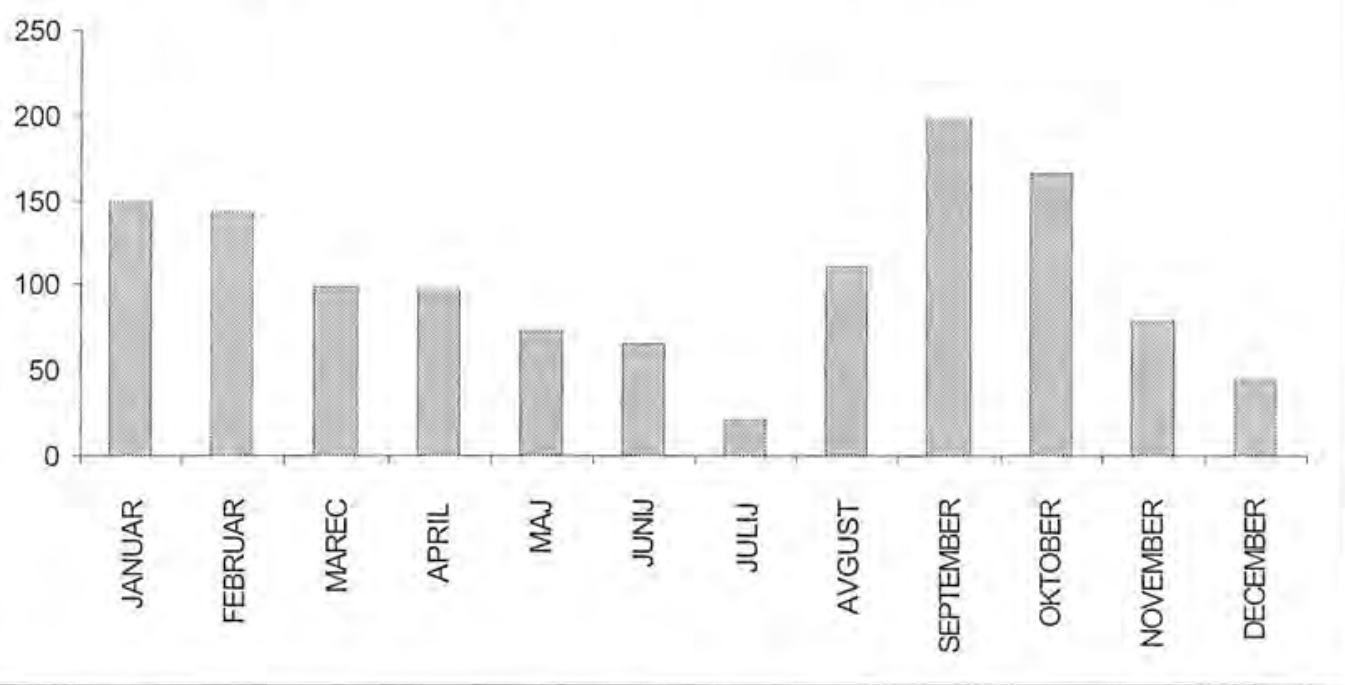

nekaj drugih, ki v okolju opazneje izstopajo.

\section{STRUKTURA OBISKOVALCEV SVETOVALNEGA SREDIŠČA PO SPOLU}

V Svetovalnem središču Novo mesto je v letu 2002 pomoč poiskalo 62 odstotkov žensk in 38 odstotkov moških. Poenostavljeno lahko sklepamo, da je delež žensk večji zaradi tega, ker je $v$ izobraževanju odraslih tudi sicer delež žensk večji kot delež moških. Izkušnje kažejo, da se moški pogosteje odločajo za formalne oblike izobraževanja, ki so povezane $\mathrm{z}$ neposrednim učinkom izobraževanja (največkrat z zaposlitvijo), ženske pa večkrat

\begin{tabular}{|c|c|c|}
\hline \multicolumn{3}{|c|}{$\begin{array}{r}\text { Tabela 2: Struktura obiskovalcev } \\
\text { svetovalnega središča po spolu }\end{array}$} \\
SPOL & št. & F $(\%)$ \\
\hline ŽENSKE & 644 & 62,10 \\
\hline MOŠKI & 393 & 37,90 \\
\hline SKUPAJ & 1037 & 100,0 \\
\hline
\end{tabular}

odločitev za izobraževanje povezujejo poleg zaposlitve tudi z osebno rastjo, družino itd.

\section{STRUKTURA OBISKOVALCEV SVETOVALNEGA SREDIŠČA PO STAROSTI}

Podatki o starostni strukturi obiskovalcev svetovalnega središča kažejo na to, da je skoraj polovica vseh obiskovalcev središča starih do 25 let.

\section{Slika 2: Struktura obiskovalcev svetovalnega središča po spolu}

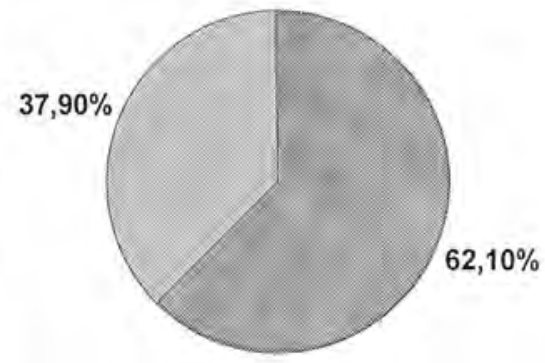

口 ŽENSKE ПMOŠKI 


\begin{tabular}{|c|c|c|}
\hline \multicolumn{3}{|c|}{$\begin{array}{l}\text { Tabela 3: Struktura obiskovalcev } \\
\text { svetovalnega središča po } \\
\text { starosti }\end{array}$} \\
\hline STAROST & Št. & $f(\%)$ \\
\hline a) manj kot 20 let & 274 & 26,4 \\
\hline b) 21-25 let & 183 & 17,6 \\
\hline c) 26-30 let & 148 & 14,3 \\
\hline d) $31-40$ let & 132 & 12,7 \\
\hline e) 41-50 let & 40 & 3,9 \\
\hline f) več kot 50 let & 75 & 7,2 \\
\hline g) ni podatka & 185 & 17,8 \\
\hline SKUPAJ & 1037 & 100,0 \\
\hline
\end{tabular}

Vzroke za relativno nizko starostno strukturo lahko iščemo v naslednjih dejstvih:

- mladi laže poiščejo pomoč kot starejši, ki jim velikokrat že sama prošnja za pomoč pomeni priznanje neuspeha, pogosto se ne želijo izpostaviti, ne vedo, kaj vprašati, se

\section{Slika 3: Struktura obiskovalcev po starosti}

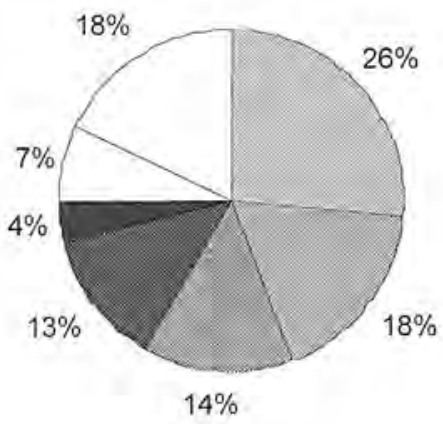

La) manj kot 20 let

ab) 21 - 25 let

c) $26-30$ let

d) $31-40$ let

e) $41-50$ let

$\square$ f) več kot 50 let

$\square$ g) ni podatka zelo hitro zadovoljijo z informacijami ...

- mlajši so pri iskanju informacij veliko spretnejši in vedo, kje poiskati pomoč,

- v programih formalnega izobraževanja je vedno več mladih, ki se za nadaljevanje šolanja kljub plačilu raje odločajo za sistem izobraževanja za odrasle na eni strani, vedno več pa je tudi osipnikov (tako osnovnošolcev kot tudi srednješolcev), ki zaradi različnih vzrokov (največkrat pa zaradi večkratnega ponavljanja) šolanja v redni obliki ne morejo več nadaljevati,

- mlajši obiskovalci so pogosto tudi redni dijaki, ki niso zadovoljni s svetovalno službo na njihovi šoli in jih $v$ središče pripeljejo starši, ki želijo poskusiti vse možnosti za rešitev otrokovih težav, pa tudi taki, ki jih v svetovalno središče napotijo njihovi svetovalni delavci na šolah, ker informacije in pomoč, ki jo potrebujejo, presegajo meje njihovega vsakodnevnega (rutinskega) dela (v večini primerov gre za nostrifikacije in nadaljevanje šolanja $\mathrm{v}$ tujini, za to pa je potreben stik s tujimi institucijami, ministrstvom, ambasadami ...),

- v svetovalno središče se po pomoč pogosto zatekajo študenti, ki po zaključku srednje šole nimajo več njim pripadajoče ustrezne svetovalne službe za pomoč pri učenju,

- veliko starejših, ki se odločajo za izobraževanje, je tudi brezposelnih in so napoteni v Program 5000; večino svetovanja za izobraževanje opravijo svetovalci na zavodih za zaposlovanje in zato ne obiščejo svetovalnega središča,

- odrasli, ki so zaposleni, velikokrat izberejo programe in oblike izobraževanja, ki jih pogojuje njihova zaposlitev, in tako dejansko nimajo dosti možnosti izbire glede različnih programov,

- starejši ljudje (tudi tisti bolj aktivni) se najpogosteje odločajo za programe v okviru že 
znane skupine (npr. različna upokojenska društva, Univerza za tretje življenjsko obdobje ...), v kateri je ponavadi omogočen tudi dober pretok informacij.

\section{STRUKTURA OBISKOVALCEV SVETOVALNEGA SREDIŠČA PO IZOBRAZBI}

Več kot tretjina obiskovalcev svetovalnega središča ima zaključeno peto stopnjo izobrazbe, sledijo jim obiskovalci s končano tretjo ali četrto stopnjo izobrazbe, končano osnovno šolo, nedokončano osnovno šolo in nazadnje tisti z zaključeno sedmo ali višjo stopnjo izobrazbe ter šesto stopnjo izobrazbe. Ljudi, ki se zanimajo za različne oblike neformalnega izobraževanja, kjer stopnja izobrazbe ni pomembna, ponavadi po izobrazbi ne sprašujemo, razen če podatek povedo sami. To je tudi vzrok za sorazmerno velik delež tistih, za katere nimamo podatka o stopnji izobrazbe.

Največjo skupino predstavljajo tisti s konča-

\begin{tabular}{|l|c|c|}
\hline \multicolumn{3}{|c|}{$\begin{array}{c}\text { Tabela 4: Struktura obiskovalcev } \\
\text { svetovalnega središča po } \\
\text { izobrazbi }\end{array}$} \\
\hline nedokončana OŠ & 102 & $\mathbf{f}(\%)$ \\
\hline končana OŠ & 123 & 11,9 \\
\hline III. in IV. stopnja & 159 & 15,3 \\
\hline V. stopnja & 375 & 36,2 \\
\hline VI. stopnja & 36 & 3,5 \\
\hline VII. stopnja in več & 88 & 8,5 \\
\hline ni podatka & 154 & 14,9 \\
\hline \multicolumn{1}{|c|}{ SKUPAJ } & 1037 & 100,0 \\
\hline
\end{tabular}

no peto stopnjo izobrazbe, razlog je najverjetneje $\mathrm{v}$ tem, da so pogosto zelo motivirani za nadaljnje izobraževanje. Velik delež v skupini predstavljajo tudi tisti mladi, ki so zaključili redno srednješolsko izobraževanje, pa zaradi različnih okoliščin niso bili sprejeti na želeno fakulteto ali $v$ katero koli drugo nadaljnje izobraževanje, ter tisti, ki so bili neuspešni med študijem in želijo zamenjati smer študija.

Ocenjujemo, da je delež tistih, ki imajo nedokončano osnovno šolo, končano osnovno šolo ali tretjo in četrto stopnjo izobrazbe, razmeroma nizek, saj so ravno ti odrasli pogosto najmanj motivirani za izobraževanje in učenje, praviloma se vključujejo le $\mathrm{v}$ formalne oblike izobraževanja (pogosto zaradi brezposelnosti ali pritiskov delodajalca). V omenjeno skupino sodijo tudi mladi, ki so osnovno ali srednjo šolo zapustili pred formalno doseženo stopnjo izobrazbe. Poleg že naštetih lastnosti pa so odrasli, ki spadajo $\mathrm{v}$ omenjeno skupino glede na doseženo stopnjo izobrazbe, pogosto prestrašeni in ne vedo, kateri podatki so tisti, ki jih potrebujejo pred odločitvijo za določeno izobraževanje.

\section{Slika 4: Izobrazbena struktura}

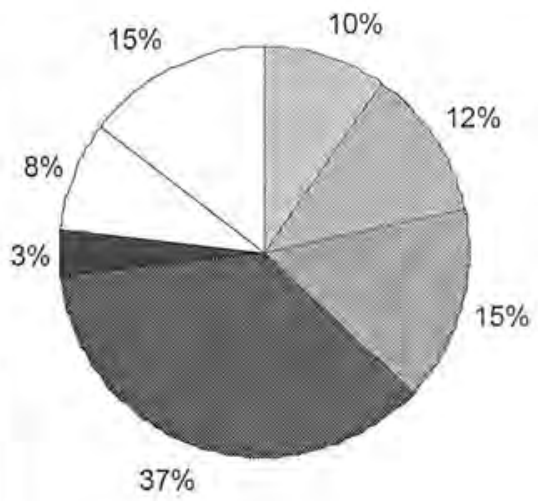

Es a) nedok. OS̆

b) končana OŠ

in c) III. in N. stopnja

d) V. stopnja

e) VI. stopnja

- f) VII. stopnja in več

g) ni podatka 


\begin{tabular}{|l|c|c|}
\hline \multicolumn{3}{|c|}{$\begin{array}{c}\text { Tabela 5: Struktura obiskovalcev } \\
\text { svetovalnega središča po } \\
\text { zaposlitvenem statusu }\end{array}$} \\
\hline št. & $\mathbf{f ( \% )}$ \\
\hline zaposlen/a & 452 & 43,6 \\
\hline samozaposlen/a & 3 & 0,3 \\
\hline brezposeln/a & 178 & 17,2 \\
\hline dijak/inja, študent/ka & 215 & 20,7 \\
\hline upokojenec/ka & 66 & 6,4 \\
\hline drugo & 12 & 1,2 \\
\hline ni podatka & 111 & 10,7 \\
\hline SKUPAJ & 1037 & 100,0 \\
\hline
\end{tabular}

Ljudje s končano šesto stopnjo izobrazbe se praviloma odločajo za nadaljevanje študija, želijo doseči izobrazbo na višji stopnji, nekaj pa je tudi takih, ki povprašujejo po različnih oblikah neformalnega izobraževanja.

Obiskovalci svetovalnega središča, ki imajo zaključeno sedmo stopnjo izobrazbe, večino-

\section{Slika 5: Zaposlitveni status}

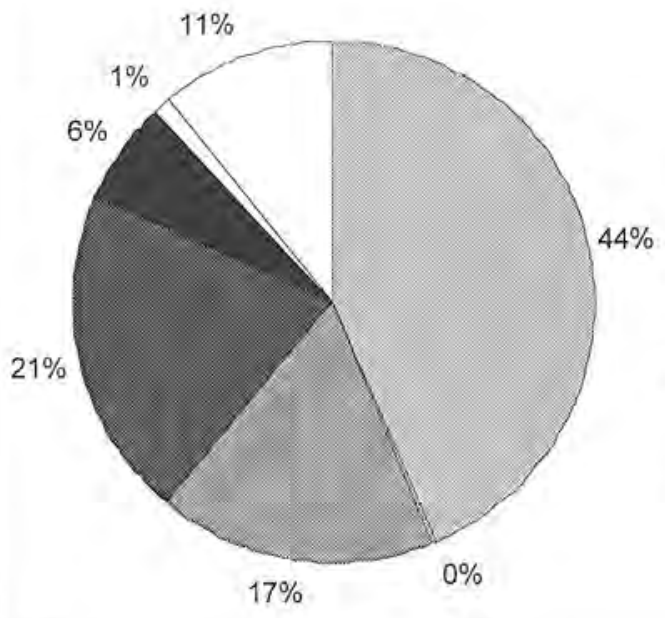

ma povprašujejo po oblikah neformalnega izobraževanja - predvsem izobraževanja, ki bi zapolnilo njihov prosti čas, in po zelo specifičnih znanjih, ki jih pogosto najdejo s pomočjo Borze znanja.

\section{STRUKTURA OBISKOVALCEV SVETOVALNEGA SREDIŠČA PO ZAPOSLITVENEM STATUSU}

Skoraj polovico vseh obiskovalcev svetovalnega središča predstavljajo zaposleni, sledijo jim dijaki in študenti, brezposelni, upokojenci ter ostali. Razlog za sorazmerno velik odstotek brez podatka je v tem, da tistih, ki se zanimajo za različne oblike neformalnega izobraževanja, po zaposlitvenem statusu ne sprašujemo.

Med zaposlenimi obiskovalci prevladujejo predvsem mlajši, stari manj kot 25 let. Brezposelni, ki poiščejo pomoč $\mathrm{v}$ svetovalnem središču, imajo pogosto zaključeno vsaj četrto stopnjo izobrazbe in želijo samo poskrbeti za svoj položaj. Manj izobraženi brezposelni se pogosto zadovoljijo $\mathrm{z}$ informacijami, ki jih dobijo na zavodih za zaposlovanje, vendar izkušnje kažejo na to, da prav ta skupina ljudi potrebuje največ pomoči. Med brezposelnimi $\mathrm{z}$ nizko stopnjo izobrazbe (nedokončana osnovna šola) je med obiskovalci svetovalnega središča tudi skupina Romov iz okolice, ki obiskujejo program osnovne šole za odrasle.

\section{VSEBINA SVETOVALNIH STORITEV}

Iz podatkov, ki smo jih nanizali, je mogoče sklepati, da večina ljudi $\mathrm{v}$ svetovalnem središču poišče informacije in pomoč glede formalnih oblik izobraževanja (pridobitev izobrazbe na višji stopnji ali prekvalifikacije), sledijo jim neformalne oblike izobraževanja za osebni razvoj, nekateri poiščejo v svetovalnem središču tudi pomoč pri učenju, nadalje sledi pomoč $\mathrm{v}$ zvezi z neformalnimi 


\begin{tabular}{l|c|c}
\hline Tabela 6: Vsebina svetovalnih storitev & Št. & $\mathbf{f}(\%)$ \\
\hline pridobitev izobrazbe na višji stopnji & 548 & 48,8 \\
\hline prekvalifikacija - sprememba poklica na isti stopnji & 83 & 7,4 \\
\hline neformalne oblike izobraževanja za delo, poklic & 55 & 4,9 \\
\hline neformalne oblike izobraževanja za osebni razvoj & 144 & 12,8 \\
\hline kako se učiti, pomoč - težave pri učenju & 57 & 5,1 \\
\hline financiranje izobraževanja & 53 & 4,7 \\
\hline drugo & 184 & 16,4 \\
\hline SKUPAJ & 1124 & 100,0
\end{tabular}

oblikami izobraževanja za delo ali poklic, financiranje izobraževanja in drugo.

Kljub temu, da večina ljudi vprašuje predvsem po pridobitvi izobrazbe na višji stopnji ali prekvalifikacijah, se pravi po formalnem izobraževanju, pa naj ob zadnji tabeli nanizamo še nekaj podatkov, ki se vežejo na posamezne kategorije. Pri neformalnih oblikah izobraževanja za delo in poklic prevladujeta jezikovno in računalniško izobraževanje ter različna krajša usposabljanja.

Za neformalne oblike izobraževanja za osebni razvoj se praviloma zanimajo ženske, ki so zaposlene ali upokojene in imajo starejše

\section{Slika 6: Vsebina obiskov}

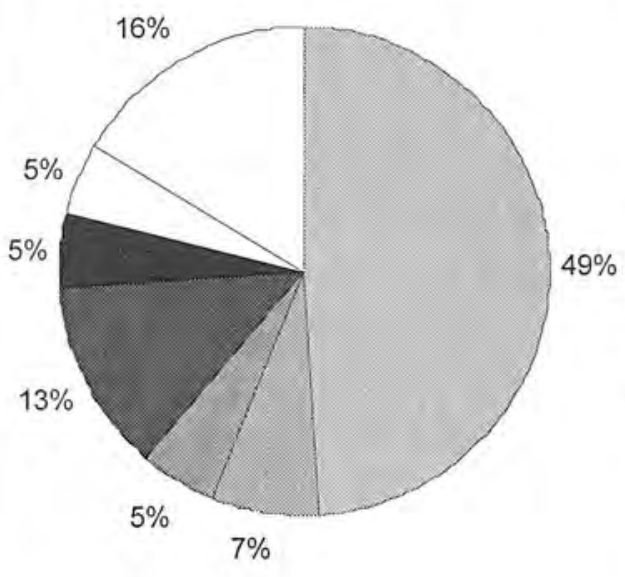

pridobitev izobrazbe na višji stopnji

prekvalifikacija - sprememba poklica na isti stopnji

ע neformalne oblike izobraževanja za delo, poklic

neformalne oblike izobraževanja za osebni razvoj

kako se učiti, pomoč - težave pri učenju

financiranje izobraževanja 


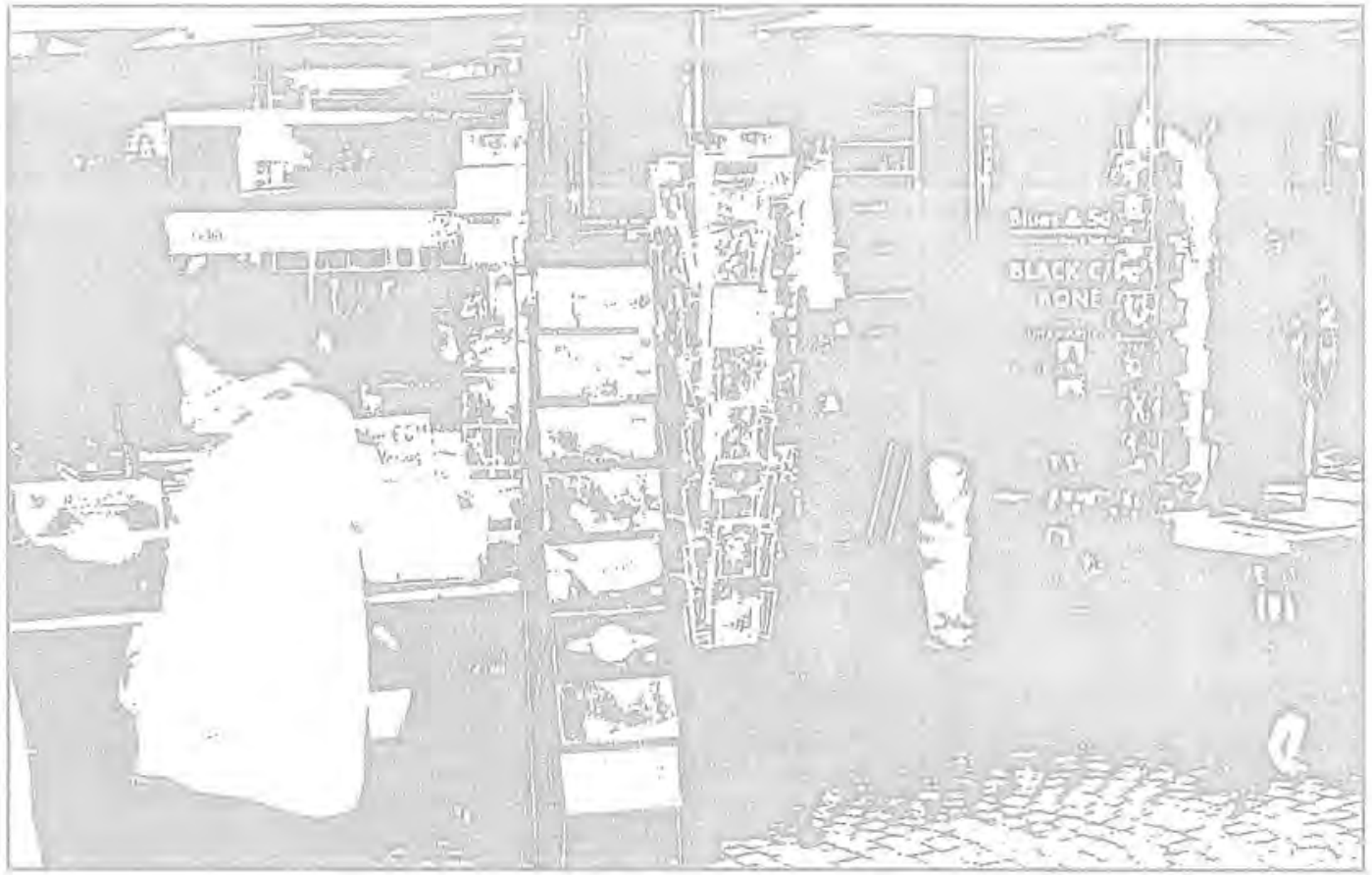

otroke. Pogosto se zanimajo za različne krajšse tečaje umetniške narave, izobraževanje v študijskih krožkih, jezikovne tečaje, pogosto pa posegajo po specifičnih znanjih, ki jih dobijo preko Borze znanja.

Pomoč pri učenju pogosto iščejo mlajši (tudi Romi), najpogosteje jim ponudimo skupinske oblike svetovanja, ki je izrazito problemsko naravnano, seveda pa težave obravnavamo in rešujemo tudi individualno.

Pri financiranju izobraževanja gre najpogosteje za pomoč pri subvencioniranju formalnih oblik izobraževanja, pogosto sodelujemo $\mathrm{z}$ delodajalci ali svetovalci na zavodih za zaposlovanje glede možnosti za vključitev v Program 5000.

Pri pomoči, ki sodi v kategorijo "drugo", gre zelo pogosto za nostrifikacije spričeval in urejanje dokumentacije za priznanje določene stopnje izobrazbe ali dela izobrazbe, urejevanja statusa študenta ali statusa udeleženca izobraževanja odraslih. Glede na to, da je Svetovalno središče lahko dostopno in obiskovalce sprejema tudi v času izven uradih ur, se ljudje obračajo tudi po različne vrste pomoči, ki včasih niso povezane $\mathrm{z}$ izobraževanjem. $\mathrm{V}$ takih primerih ljudi napotimo $\mathrm{v}$ druge, za to ustreznejše ustanove.

\section{ZAKLJUČKI}

Večina ljudi, ki poišče pomoč v Svetovalnem središču Novo mesto, se zanima za pridobitev stopnje izobrazbe ali kvalifikacije, ki je povezana $z$ zaposlitvijo. Ljudje najbolj povprašujejo po možnostih za formalno izobraževanje, manj pa po neformalnih oblikah izobraževanja, ki jih potrebujejo za lastno zadovoljstvo ali kakovostno preživljanje prostega časa.

Skupina ljudi, ki poišče pomoč, obisk v središču pogosto pojmuje kot eno izmed dodatnih možnosti za informacije ali svetovanje. Verjetno je potrebno razmišljati, kako doseči in vzpodbuditi tiste, ki na svoji poti ne posežejo po pomoči, ki jim je na voljo; s tem mislimo predvsem manj izobražene, starejše, moške, brezposelne ... $\mathrm{Z}$ vidika omenjene 
skupine je ena izmed primarnejših nalog svetovalnih središč ne le zadovoljevanje potreb med izobraževalno ponudbo in posameznikom, ki se želijo učiti, temveč prepoznavanje in razvijanje potreb tistih, ki lastnih potreb po izobraževanju in učenju ne razvijejo oziroma jih ne prepoznajo. Eden izmed načinov takega spodbujanja je prav gotovo ponujanje zadostnih in posameznikom razumljivih informacij, približevanje izobraževanja določenim slojem in ciljnim skupinam ter predstavljanje in nenazadnje tudi pomoč pri učenju $\mathrm{v}$ vseh drugačnih in alternativnih poteh na poti do izobrazbe.

Če stvar osvetlimo tudi z nekaterimi tezami o permanentnem izobraževanju, ki smo jih nanizali $v$ uvodu, lahko vlogo svetovalnih središč vidimo tudi $v$ spodbujanju posameznikov za različne oblike neformalnega izobraževanja, ki naj bi v prihodnosti pridobivalo enako težo in pomen kot formalne oblike izobraževanja. Ljudi je potrebno navaditi, da $v$ učènju začnejo prepoznavati tudi elemente, ki pomenijo več kot le potrdilo ali dovoljenje za opravljanje določenega dela, in da ob lastnem učenju začnejo opazovati tudi nekatere druge spremembe, ki jim jih učenje prinaša. S takim načinom bi posameznikom lahko približali učenje in jih motivirali za poseganje po novih učnih možnostih.

Končamo naj $z$ idejo o enakosti izobraževaInih možnosti. Kljub vse naprednejšim potem za dosego izobrazbe in učenja to še vedno predstavlja privilegij in je vedno materialno pogojeno. Lahko pa za začetek veliko bolj realno govorimo o zagotavljanju enakih možnosti do dostopa informacij in oblik pomoči ob odločanju za učenje. V nekaterih državah (npr. Irska), kjer je svetovanje za izobraževanje dokaj razvito, poznajo obliko delovanja podobnih središč, ki jo imenujejo "reach out". To pomeni, da svojo pomoč ponujajo v središčih, kjer se določena skupina ljudi giblje. S takim načinom ljudem v njihovem okolju prikazujejo možnosti, ki jih ponuja učenje ter najbolj učinkovito odpravljajo ovire, ki posameznike odvračajó od učenja. Tudi v našem okolju bi po podatkih, ki smo jih zbrali za leto 2002, kazalo posebno pozornost posvetiti ljudem, ki $v$ središče ne prihajajo, in jim morda ponuditi in predstaviti učenje $v$ vsakdanjih okoljih, kjer živijo in se gibljejo, ter na način, ki jim je blizu.

\section{LITERATURA}

A European Area of Lifelong Learning, Luxembourg (2002). Office for Official Publications of the European Communities.

Field, J., Leicester, M. (2000). Lifelong learning: education acsoss the life span, London: Routledge.

Filipovič, D. ( 1971). Permanentno obrazovauje: suština i konzekvence. Leskovac: Naša rečc:

Jelenc, Z. (1980). Svetovalno delo nat področju izobraževanja odraslih. Ljubljana: Filozofska fakulteta. Skripta za študente.

Jelenc, Z. (1989), Odrasli prebivalci Slovenije v izobraževanju. Ljubljana: Pedagoški inštitut pri univerzi Edvarda Kardelja v Ljubljani in Skupnost izobraževalnih centrov v Sloveniji.

Jelenc, Z. (1998). Vseživljenjsko izobraževanje in vseživljenjsko učenje. Ljubljana: Andragoški center Slovenije.

Kristanččc, A. (1995). Svetovanje in komunikacija. Ljubljana: Združenje svetovalnih delavcev Slovenije.

Lengrand, P. (1976). Uvod u permanentno obrazovanje, Beograd: Beogradski izdavačko-grafički zavod.

Lifelong Learning and Lifewide Learning (2000). Skolverket.

Longworth, N., Davies, K. W. (1996). Lifelong learning. London: Kogan Page.

Oliver, P. (2001). Lifelong and Continuing education: What is a learning society, Burlington: Ashgate.

Sutcliffe, J. (1990). Adults with Learning difficulties. Education for choice \& Emprowment: A handbook of a good practice. Leicester: NIACE.

UDACE (1986), The challenge of change. Developing educational guidance for adults. London: NIACE. 
Vilič Klenovšek, T. (1998a). Informiranje in svetovanje brezposelnim za izobraževanje. V Vzgoja in izobraževanje, št. 5, str. 27-31.

Vilič Klenovšek, T. (1998b). Svetovalna dejavnost v izobraževanju odraslih. Stanje in potrebe v Sloveniji v obdobju 1997/98. Sintezno poročilo. Ljubljana: Andragoški center Slovenije.

Woolfe, R. (1987), Guidance and Counselling in Adult and Countinuing Education. A Developmental Perspective. Philadelphia: Open Universitiy Press. 